Periodica Polytechnica Architecture, 49(2), pp. 135-143, 2018

\title{
A Sustainable Urban Concept for Housing Estates: Plot, Patch, Part
}

\author{
Regina Balla ${ }^{1 *}$ \\ ${ }^{1}$ Department of Urban Planning and Design, Faculty of Architecture, Budapest University of Technology and Economics, \\ H-1521 Budapest, P.O.B. 91, Hungary \\ * Corresponding author, e-mail: balla.regina@urb.bme.hu
}

Received: 16 May 2018, Accepted: 11 June 2018, Published online: 29 November 2018

\begin{abstract}
While, in practice, the rehabilitation of prefabricated housing estates has mostly focused on the buildings, a comprehensive concept, which is able to revalorise this problematic housing stock has become increasingly relevant. The specific, holistic proposal of the revalorisation demands an interdisciplinary approach, based on urban planning principles of SUN (sustainable urban neighbourhoods), that can reconceptualise housing units on the different scales as plot, patch and part of a city or town. To find proper methodology, this paper attempts to adopt an approved evaluation tool used in the field of property development. Property development strongly adheres to various certification systems. These apply not only to buildings, but on the urban scale, neighbourhoods can also achieve good qualification in systems like LEED Neighbourhood. This study argues that the requirements of LEED Neighbourhood can be adequately applied in the case of existing housing estates; as a result of which, they could become less isolated and could be more easily integrated into the neighbouring urban network as sustainable parts of cities and towns.
\end{abstract}

Keywords

housing estate, neighbourhood, certification system, sustainability

\section{Introduction}

In Central and Eastern Europe, around 150-170 million people live in prefabricated housing estates. In Hungary, 1.9 million such residents are registered, while the ratio of housing estates within cities and towns is changing (Csizmady, 2003).

As Fig. 1 shows, in 1970-71, the general development concept extended to many Hungarian cities (Körmendi, 1973). Next to industrial and public institutional projects, in most cases, it involved housing estate construction. In Communist new towns like Dunaújváros (Stalin City 1951-1961) or Tiszaújváros (Lenin City 1970-1991) and in expanded industrial towns like Paks, the silhouette of the housing estates dominates the urban landscape.

People mostly have negative opinions about this type of housing, mainly because of the technology of prefabrication. Globally, it should be noted that the surveys of the building stock evidence that with proper maintenance, the structure of the houses can endure for the next 50-100 years (Ambró et al., 1996). Also, if refering only to technological issues, even today, prefabricated housing developments are widespread in those countries where urbanisation is progressing strongly. Although governmental and professional agencies (Egedy, 2000) have different opinions and concepts regarding this housing stock, because of the high ratio, in the near future, prefabricated housing estates will still characterise the physiognomy of cities.

Considering the situation from the year 2000, the renovation of housing blocks started with thermal insulation and changing the windows. In some cases, the rehabilitation of public spaces is also moving forward (Gábor et

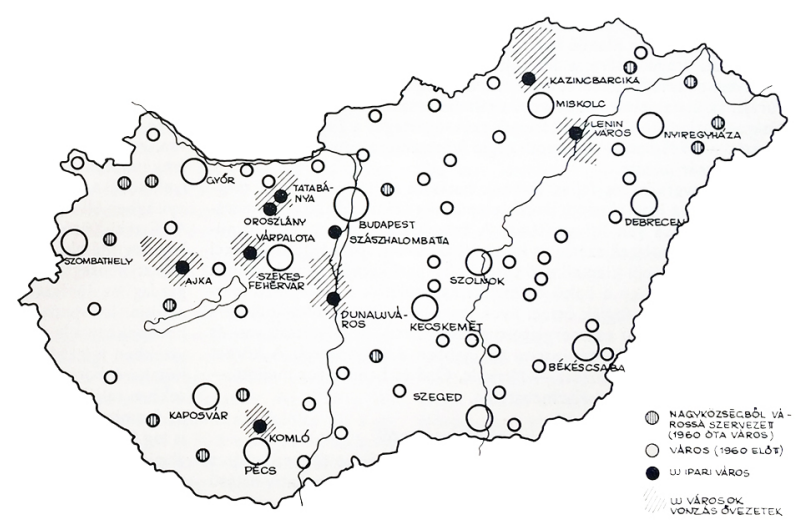

Fig. 1 New towns in the regional urban network, (Körmendi, 1973) 
al., 2015). Furthermore, there are examples of modernisation of mechanical engineering systems that can improve housing conditions (Gere, 2012). Despite this, there is no overall programme aimed at managing this issue in the near future. In the last ten years in Hungary, there were only local attempts for integrated programmes such as the social rehabilitation project in the Havanna housing estate in Budapest (HitesyBartuczHollai Euroconsulting Kft., 2014).

When examining real estate data, the endeavours seem successful as property prices (ingatlannet.hu, 2018) show that prefabricated housing blocks are popular among home buyers; real estate experts are talking about a "panel reneszánsz" ("renaissance of housing blocks") (Marnitz, 2017). However, the question is whether this a real improvement or just a change in the way of life that may hide social problems? The housing estates can offer well-being in a limited framework, which paradoxically results in positive features that secure avenues for a sustainable future. These features can be, for instance, the high ratio of green area, walkability, high density and rich mix of uses. In many Hungarian small and mid-sized towns, the service facilities of the units are often more developed than in other parts of the urban area (Benkö, 2015). These are also defining elements of the Sustainable Urban Neighbourhood (SUN) concept (Rudlin and Falk, 2009).

The research does not focus on the positive change in the attitudes of home-seekers towards housing estates; instead, it aims to explore those factors that researchers believe support the view that housing estates have special potential in a sustainable urban development process. Furthermore, the examination raises important issues regarding city size and its area covered by housing estates.

\section{Methodology}

\subsection{Scale of study}

If we are referring to the doctrines of Le Corbusier and the CIAM (Frampton, 2007), the basic aims of urban planning are separation and organisation of housing, working, leisure and mobility functions according to use. Its implementation is shown in Fig. 2.

Further, the adaptation of the points of the Athens Charter to real life can be questionable (Le Corbusier, 1973). The pressure of efficiency was numerically calculated, and

3. habitable

way of implementation

Fig. 2 The problematic implementation of modernist architectural principles, based on Csizmady, (2008) planning had to follow quantifiable standards. Consequently, instead of the freedom of architectural creation, the planning of housing estates was determined by bureaucratic requirements. As the research focuses on territorial aspects, it is important to highlight points 86,87 and 88 of the Charter, which reflect the original approach:

- 86. "The architect engaged in town planning should determine everything in accordance with the human scale."

- 87. "The point of departure for all town planning should be the single dwelling, or cell, and its grouping into neighbourhood units of suitable size."

- 88. "With these neighbourhood units as the basis, the urban complex can be designed to bring out the relations between dwelling, places of work and places devoted to recreation." (Le Courbusier, 1946)

The urban form of a mass housing estate can be characterised by a special territorial structure that can be examined in three different urban scales: plot, patch, part of the city.

The delineation of these scales can be represented by the master development plan of the cities, which can present closely similar details on a small scale, but as we draw back, the character of the examined city becomes increasingly important (Fig. 3). It is considered appropriate to compare the former points of the Athens Charter with the three different scales. The accomplishment of the human scale can be examined by the close surroundings of the housing block that is a plot. The size of units can be different, but their border usually defines the patch of the estate. The integration of a housing estate, the whole as part of the city, can be valuable for the complete urban network. The objective of this study is to improve these propositions, and it looks for suitable tools for implementation.

\subsubsection{Housing estate by plots}

In the case of mass housing estates, this is frequently an invisible spatial border containing the urban footprint of the building and its $1 \mathrm{~m}$ wide surrounding ground. In Hungary and neighbouring Austria, by this 1-meter wide zone, the transition spaces of these building units (Fig. 3 (a)) can result in a questionable situation regarding use. In some cases, inhabitants occupy territories outside the border, in others, the transition zone becomes a no man's land. The architectural elements of this zone can widen and lengthen the transition zones with various tools as the author examined in earlier studies (Benkő and Balla, 2016); although, in point of use, 


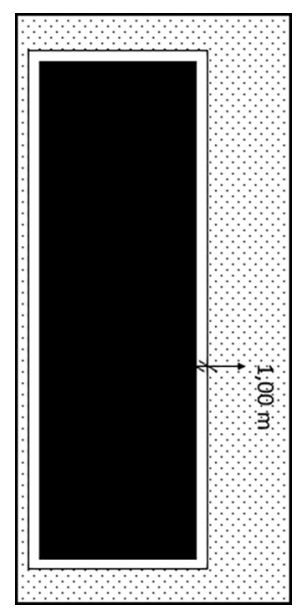

(a)

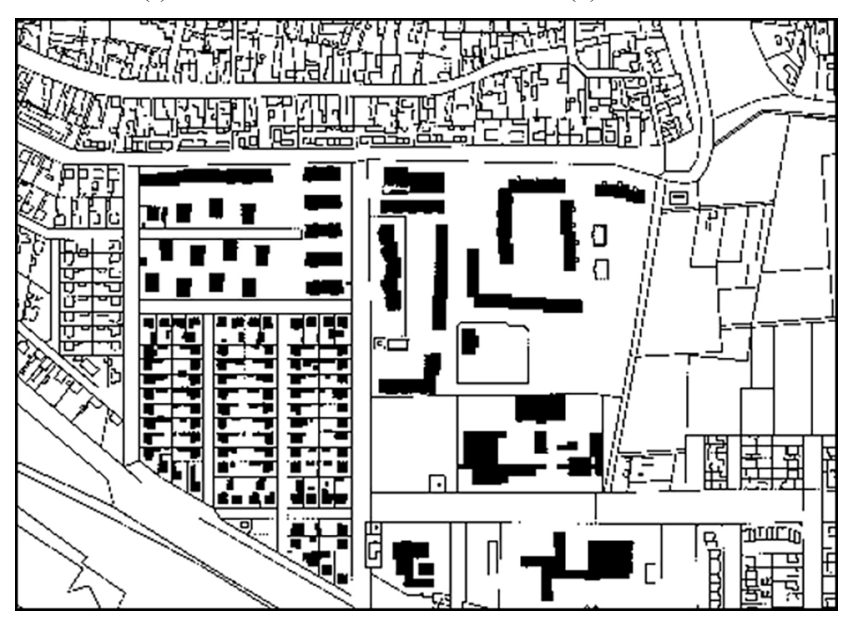

(c)

Fig. 3 (a) A block of flats with adherent plot, (b) The patch of Bökény Housing Estate in the town of Csongrád, (c) Housing estate is part of the Bökény district in the town of Csongrád, drawings created by the author

clarifying possession is a more urgent issue. The surrounding territory of the plots in Hungary is state property but in other Central and Eastern European countries this may have changed. For example, in the Czech Republic, after 1990, it was divided and returned to earlier ownership; consequently, today, the plots can be "floating" on two or even three different owner's grounds. In this way, the clarification of territorial issues of these zones could be a step forward in future rehabilitation projects, but just with considering the historical regulator provisions (Benkő and Balla, 2016).

\subsubsection{Housing estate as a patch}

A housing estate has special legal status, size and composition. The cluster of the housing estate area represents a specific land use, indicated as fragmentation in the landscape, that is defined as a patch (Fig. 3 (b)). The patch is identifiable by the modernist flowing space that usually belongs to the state and the houses occupied by the residential community. Additionally, it is important to note that a housing estate patch always has an own defined name, even if it is part of a named city district (Balla, 2016). This distinction creates not only architectural issues but also social and economic ones, especially if referring to statistical surveys or distribution of resources. The current question concerns the possible solution for changing the structure, expanding diversity and density of the patch or just emphasising the territorial border to clarify the roles of a city in the responsible development of housing estate patterns. From the point of view of urban planning, it is increasingly urgent to analyse the advantages and disadvantages of this strong isolation of the individual housing units. Furthermore, the examination of the unit as a patch recalls similarities with the sustainable neighbourhood concept (Perry, 1929) that was born around the same time as the notion of the microraion (Körner and Nagy, 2006); this was the communist basic urban concept for the planning of housing estates.

\subsubsection{Housing estate as part of the city}

In the 1950s, many cities established social and administrative institutions just in the city centre, although, some of these, like health centres, were not developed at all. From the 60 s to the $80 \mathrm{~s}$, housing estates, with their systematically planned institutional network, changed the functional structure of cities (Csizmady, 2003). In this respect, it is worthwhile concentrating on the differences between bigger and smaller cities. Many times, because of the compact concentration of mixed-use, these parts of the city could have the role of a second centre. The functional coverage was more or less satisfying during the said era, but in many situations, the integration of the patch into the neighbouring areas and its accessibility within the city as a whole was not well coordinated. Future urban planners need to analyse the segregated situation of the housing units and create possibilities for change (Fig. 3 (c)).

\subsection{Tool of analysis}

The urban design model of SUN initially emerged in 1990 in the UK, as part of an urban reform that attempted to bring together $20^{\text {th }}$ century urban theories regarding sustainability on the scale of the urban neighbourhood. One of the critics of this approach argued that SUN is a collection of impressive ideas but cannot propose a real conventional methodology or measurable analysis. Additionally, the social and political 
level of the model was also incomplete, which raises a considerable number of questions, mainly in the case of housing development within an urban neighbourhood. Therefore, this analysis proceeds from a social proposition, towards the proposal of the measuring. In this way it highlights the connections of the disciplines in the research topic.

In the discussions about housing, well-being is often referred to first, the aim being that the residents will like their housing environment. In this respect, the different sociological surveys show similar results: when researchers asked the residents of a housing estate about their opinion, they mostly complain about the following seven issues (Csizmady, 2008):

- difficult accessibility (A)

- large undefined public spaces (B)

- poor service facilities (C)

- bad condition of the lobby and the staircase (D)

- expensive district heating (E)

- too little floor area of apartments (F)

- social problems: estrangement between the residents, criminality, drug use, vandalism (G).

Of these issues, three (A, B, C) can be examined through the third scale of study, according to "part of the city". Two of them $(\mathrm{E}, \mathrm{F})$, which are independent, concern the scale of a building, whereas the remaining $(D, G)$ are related to the urban scale, the proof of which is one of the concerns of this study. Nevertheless, issues A, B, C + D, G can be compared with those sustainable urban planning strategies that Lukovich and Mogyorósi (2013) define in their book on sustainable development regarding settlement pattern and land use. The main principles outlined are:

- polycentric city structure

- horizontal and vertical functional diversity

- adequate quantity and quality of public space

- a systematic linear infrastructure network

- interconnected green area network

- balance between green and built environment

- adequate density standard and concentrated coverage form

All of which can be implemented in the case of housing estates and thus change their negative perception (Lukovich and Mogyorósi, 2013). However, strategic planning is a method for examining development, whereas these are principles.

Today, in property development, supply and demand are subordinated to various certification systems. These apply not only to buildings but on an urban scale; new neighbourhoods can also achieve high levels of qualification. The applied assessment system for this research is the LEED Neighbourhood Development. This system is an American national set of standards for neighbourhood location and design based on the combined principles of smart growth, new urbanism, and green infrastructure and building, which all appear in the SUN model. According to the achieved credits, projects can be classified as silver, gold, or platinum LEED certification. This qualification is profitable in the property market (USGBC, 2018). Comparative research pointed out that, surpassing other recognised systems such as BREEAM or DGNB, LEED indicators are the most committed to urban level (Orova and Reith, 2015). The most achieved credits in the assessment system can be fulfilled in the categories of resources, location, infrastructure and transportation. The latter is developed for new projects, but mainly focus on these categories; there is also an effort to apply it to the rehabilitation of existing projects (Gelesz, 2012). In this way, the LEED rating system can be used to guide improvements to an older urban unit or a prefabricated housing estate.

Since the LEED guidelines are already often applied during the planning process, they could be regarded as planning principles. These principles are then translated into measurable data.

Returning to the bureaucratic implementation of housing estate projects, which were also defined numerically, as the following shows, these guidelines are very detailed and try to take into account not only the direct hard factors of sustainability such as infrastructure, but increasingly, tests that involve soft factors that are, essentially, the liveability of an urban area.

Not all prerequisites and credits of the LEED Neighbourhood system are relevant in the case of this study, however, according to Table 1, 37 factors are applicable in these aspects and 18 in the scales of examination. Evaluating the Smart Location and Linkage (SLL) of existing city parts is not as relevant, segregated estates can be qualified as low, for example, the Újpalota estate, that was built on a greenfield site on the outskirts of Budapest. Characterising the Neighbourhood Pattern and Design (NPD) of units is significant. Criteria regarding Green Infrastructure and Buildings mostly concern the scale of the buildings in the area; just a few credits can be calculated on an urban scale. The other criteria of Innovation (IN) and Regional Priority (RP) are connected to the social and financial management of the area, which is also significant. However, the study underperforms in this respect. 
Table 1 Selection from indicators of the LEED Neighbourhood certification system, created by the author (USGBC, 2018)

\begin{tabular}{lcccc}
\hline Group of indicators & SLL & NPD & GIB & IN \& RP \\
\hline $\begin{array}{l}\text { Number of credits } \\
\begin{array}{l}\text { Applicable credits in } \\
\text { case of the housing }\end{array}\end{array}$ & 9 & 15 & 17 & 3 \\
$\begin{array}{l}\text { estates } \\
\begin{array}{l}\text { Related credits to the } \\
\text { urban scales }\end{array}\end{array}$ & $\mathbf{4}$ & $\mathbf{9}$ & $\mathbf{5}$ & $\mathbf{0}$ \\
\hline
\end{tabular}

The aim of the following research to improve sustainable development strategies are adequate in the case of housing estates. The selected 18 indicators for housing estates can be accomplished, and they can result in good credits concerning sustainable strategic issues on an urban scale. In the following analysis, the housing estates were chosen from different cities in Hungary, but certain good examples from other countries are also mentioned.

\section{Research results}

\subsection{Plot}

It is worthwhile viewing prefabricated housing blocks with respect to the territorial framework. In Hungary, the outline of the $1 \mathrm{~m}$ wide zone around the blocks does not include a physical border between "private" and public, and instead, the ground floor of the blocks creates the boundary. However, this zone defines the relationship between outside and inside, urban and private, creating a semi-private transition zone. For the residents, this is the architectural framework of the social interactions that happen in a leftover space resulting from the use of prefabrication. In this zone, the house factory (Házgyár) technology posed limits to the community needs and the concerns of placemaking; the ground floor of the blocks was a prefabricated monolith concrete basement that was often built half or totally under ground (Ambró et al., 1996). With this unpleasant contact to the outside, and because composing a well-functioning and aesthetic transition zone was impossible, the

Table 2 LEED Neighbourhood indicators related to the scale of the plot, selected by the author, (USGBC, 2018)

\begin{tabular}{lc}
\hline $\begin{array}{l}\text { Number of } \\
\text { Indicators }\end{array}$ & Level of PLOT \\
\hline $\begin{array}{l}\text { Strategic elements: adequate density standard and concentrated } \\
\text { coverage form, horizontal and vertical functional diversity }\end{array}$ \\
1 & Bicycle Network and Storage \\
2 & Heat Island Reduction \\
3 & On-Site Renewable Energy Sources \\
4 & Solid Waste Management Infrastructure \\
\hline
\end{tabular}

boundaries of the plots were marked very close to the blocks. In Hungary, there are some examples where architects, such as Csaba Virág in the Havanna estate, tried to append characteristic elements; he planned spaces and frameworks for small shops and services on the ground floor. Another well-known questionable case is the separation of the pedestrian streets from the ground that could not realise finally either around the houses of the Újpalota estates in Hungary (Benkő et al., 2018).

Generally, most built projects show a very pure collection of elements. Today, it is a recurring problem, as to whether the buildings are accessible to people with reduced mobility, including at least one wheelchair user, in addition to the concerns for public safety and the conditions of the transition zone (Benkő and Balla, 2016). It is not possible to apply these measures to the legal territory surrounding the block.

If we examine the requirements of sustainability, cycling is a critical question because of larceny, mainly in bigger estates. In addition, cycling culture is not so common in areas with high traffic, nor in big cities because of the lack of suitable infrastructure. However, these large-scale questions are beyond the scope of this study. Otherwise, in small to mid-size Hungarian towns, where the topographical conditions allow it, cycling is traditionally widespread. Here, in and around the blocks, it should be a fundamental task to provide good and secure bicycle racks. The separated collection of waste and the recycling of materials and energy is an essential requirement, which could find suitable space on the ground floor's unused, empty areas.

In this respect, there are a growing number of good examples: in Krems in Austria, the entrances are barrier-free, and we can find little private gardens around the blocks that are also used for drying laundry since this zone is connected with the basement washing room.

\subsection{Patch}

The scale of the patch is the most complex issue, many of the related indicators could help in evaluating the housing estates, but long-term transformation needs not only social and architectural but primarily economic support. For this reason, this is the least established development alternative. In choosing some elements, it is possible, for example, to reduce the car parking footprint through building underground garages or promoting car sharing. However, the problem with these stems from the complexity of these developments. They have to be planned in as part of a 


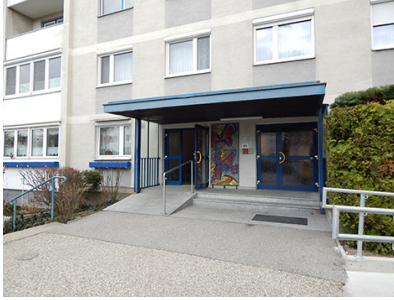

(a)

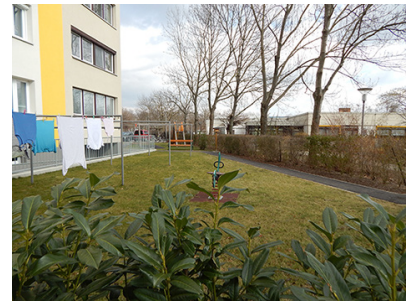

(b)
Fig. 4 The city of Krems in Austria, Housing estate in Mitterrau (a) entrance of a housing block. (b) private gardens around a housing block. Photos taken by the author

long-term process that can increasingly valorise the territory. In practice, every Hungarian city has to prepare a territorial development documentation (ITS). This documentation assesses the actual condition of the individual parts of cities and defines the short, medium and long-term plans concerning these areas (subsection (27) of section 2 of Act LXXVIII. of 1997 on the formation and protection of the built environment - Hungarian Act). Well-Constructed planning documentation should contain a timetable of the implementation and assign financial resources to the projects. In practice, in Hungary, the main problem is that in

Table 3 LEED Neighbourhood indicators related to the scale of the patch, selected by the author, (USGBC, 2018)

\begin{tabular}{|c|c|}
\hline $\begin{array}{l}\text { Number of } \\
\text { Indicators }\end{array}$ & Level of PATCH \\
\hline \multicolumn{2}{|c|}{$\begin{array}{l}\text { Strategic elements: adequate quantity and quality of public space, } \\
\text { interconnected green area network, balanced between green and built } \\
\text { environment, horizontal and vertical functional diversity, density } \\
\text { standard and concentrated coverage form }\end{array}$} \\
\hline 1 & Bicycle Network and Storage \\
\hline 2 & Heat Island Reduction \\
\hline 3 & On-Site Renewable Energy Sources \\
\hline 4 & Solid Waste Management Infrastructure \\
\hline 5 & Locations with Reduced Automobile Dependence \\
\hline 6 & Housing and Jobs Proximity \\
\hline 7 & Restoration of Habitat or Wetlands and Water Bodies \\
\hline 8 & Walkable Streets \\
\hline 9 & Compact Development \\
\hline 10 & Mixed-Use Neighbourhood Centres \\
\hline 11 & Reduces Parking Footprint \\
\hline 12 & Street Networking \\
\hline 13 & Access to Civic and Public Spaces \\
\hline 14 & Access to Recreation Facilities \\
\hline 15 & Local Food Production \\
\hline 16 & Neighbourhood Schools \\
\hline 17 & $\begin{array}{l}\text { Minimised Site Disturbance in Design and } \\
\text { Construction }\end{array}$ \\
\hline 18 & Stormwater Management \\
\hline
\end{tabular}

many of the ITS documents little attention is paid to housing estates, and the related proposals are very elementary. If the development plans are about to be implemented, the next question should concern the regulation of the territory, since the prospects of neighbourhood development projects, be it the designing of community gardens or building a new community centre, might require the creation of new borders in the patch. In addition, the achievement of positive results (Fig. 5) in a certification programme should not be viewed only as something to check off.

In this regard, it is worth considering the trend of community gardens. To create gardens to establish a new function for undefined public spaces on an estate may seem to be a good idea at first, like for example in Budapest, where these initiatives flourish (e.g. the "Menta Community Garden" at the Lakatos housing estate). However, what about the "panel society" of the provincial towns? It is interesting to refer to some interviews with early residents, who had very good opinions regarding their homes. Many housing estate residents owned vineyards and allotments around the city. Did this situation survive to this day? In a small Hungarian town like Csongrád, it is possible to buy a minor vineyard from 150 Euros, yet these types of areas are either conspicuously deserted, or a large company cultivates them. Thus, the answer is more likely to be "no", we are witnessing a social change today, and community gardens may not be a solution for the reuse of undefined public spaces.

\subsection{Part of a city or town}

The examination of the housing estate as part of the city is a very important and still underestimated process. The critics of modernism claim that one of the biggest problems of housing estates is that a unit reflects a logical system

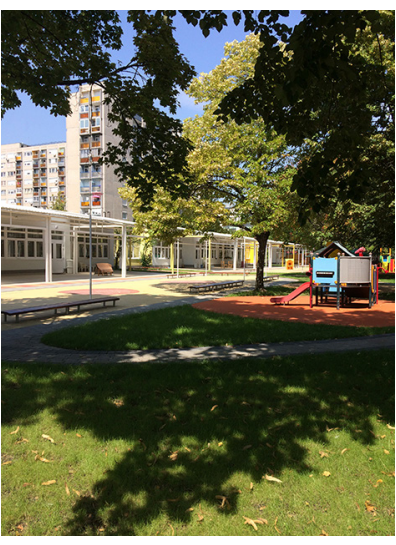

(a)

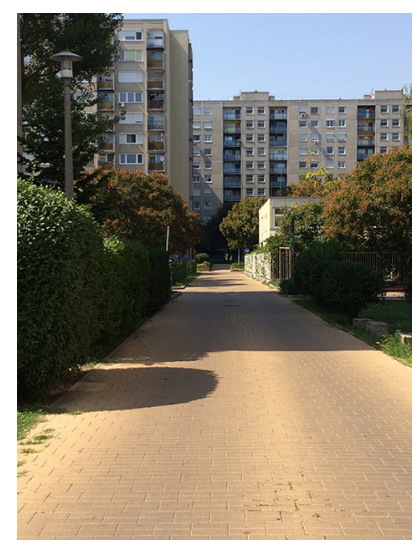

(b)
Fig. 5 Vizafogó housing estate, (a) development of the kindergarten, (b) renewal of public spaces, Photos taken by the author 
from above, but it is too complicated and abstract from the human eye on the ground (Klasander, 2005). The eyelevel human perception of space is more relevant for the scale of the lot or that of the patch, but from system theory (Lukovich, 2001), housing estates offer exciting prospects for research. Also, regarding questions about traffic infrastructure organisation, but mainly in the case of polycentric city model theory (Fleischer, 2009), housing estates are easily analysed according to their integration and connectivity to the urban fabric. It is necessary to determine how possible it is to integrate the unit into the circulation of the city; this can be a good approach if, primarily, we are looking for a territory to develop a new urban area. Housing estates can be an appropriate choice when creating a new district from a neighbourhood because they usually have a good functional institutional system - for example a primary school in the unit receives children from the ages of 6-14 and also from the newly developed area. This way, it is possible to maintain the school of an estate, it does not have to close, which often happens in Hungary, even in small towns. To find the suitable connectivity system, it is worth analysing the system of linear infrastructure, comparing the present situation with the planned one. It will show how the new system must replace the old one to strengthen the integration of the given part of the city. In addition to traditional morphological studies, space syntax method can show the systematic spatial relationship. The theory of space syntax is defined by the encounters and its control, besides the spatial configurations that are based on the socio-spatial experiences of the inhabitants and new arrivals to the city / city parts (Hillier and Hanson, 1984). In the research of a whole settlement, space syntax can present those parts of a city which are:

- the centres

- the sub-centres (that can also be housing estates)

- the peripheral areas

Table 4 LEED Neighbourhood indicators related to the level of the urban block, selected by the author, (USGBC, 2018)

\begin{tabular}{lc}
\hline $\begin{array}{l}\text { Number of } \\
\text { Indicators }\end{array}$ & Level of CITY / TOWN \\
\hline $\begin{array}{l}\text { Strategic elements: polycentric city structure, thoughtful line } \\
\text { infrastructure network }\end{array}$ & Bicycle Network and Storage \\
1 & Housing and Jobs Proximity \\
6 & Street Networking \\
10 & Access to Recreation Facilities \\
12 & Neighbourhood Schools \\
14 & \\
\hline
\end{tabular}

- the important aspects of transit traffic (Fürstand, 2007).

In the Hungarian city of Paks, a housing estate was built between 1975 and 1979 for the employees of the nuclear power plant, and at present, after almost forty years, as the state is expanding the power plant, the municipality is looking for new areas for housing (Hallek, 1974).

One of the projects might be realised next to the "Erömü lakótelep" (Power Plant housing estate) that will also utilise the housing estate's services and helps the integration of the estates into the city through a ring road surrounding the town. The latter was planned in the seventies, and its completion was prompted by the new housing project. The following space syntax analysis shows the transformation of the settlements. The control and integration of the various spatial elements, in this case, the lines of the street network, can be classified; the analysis describes the position of a street in the settlement structure. From the peripheral areas towards the city centre, lines have high control (Fig. 7 (c-d)) and strong integration rates (Fig. 7 (a-b)), which are linked by the ringed lines, also with strong integration, but weak control rates. The integration maps effectively present the strong role of the housing estates and the relationship to the new unit. Summarising the experiences of the examination, the achieved LEED credits can be easily calculated in case of the Power Plant housing estate.

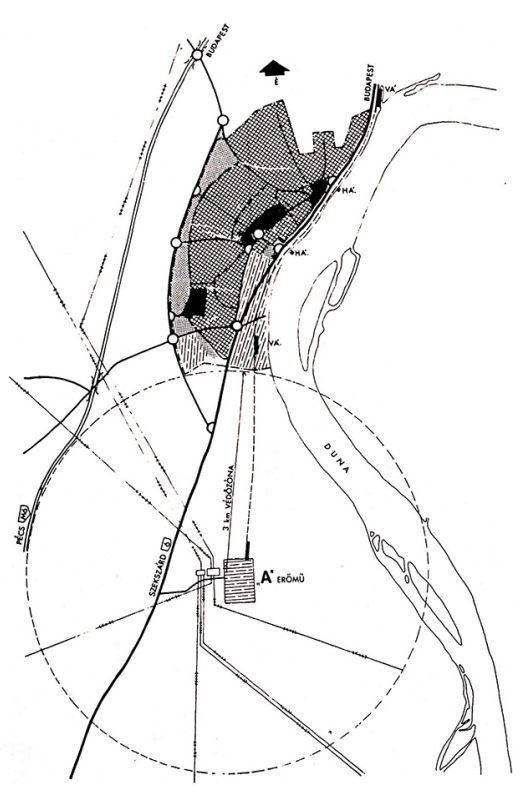

Fig. 6 Development of Paks, by Hallek, (1974). 


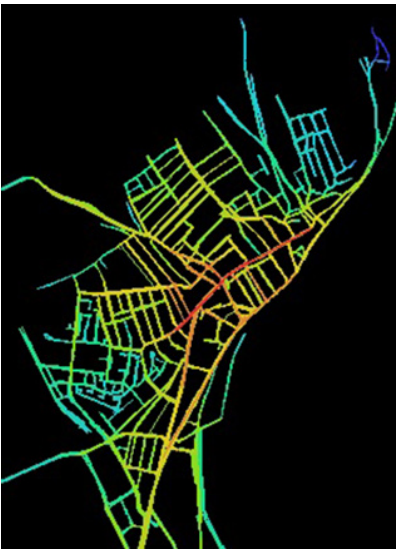

(a)

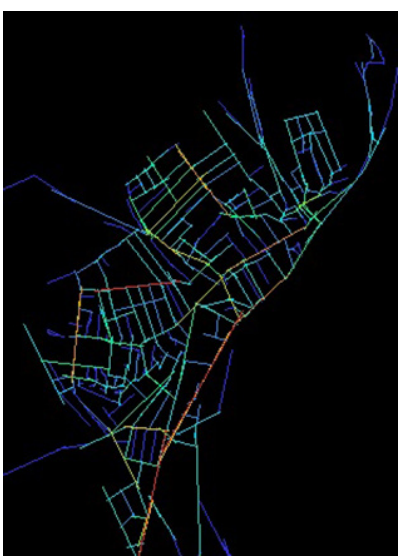

(c)

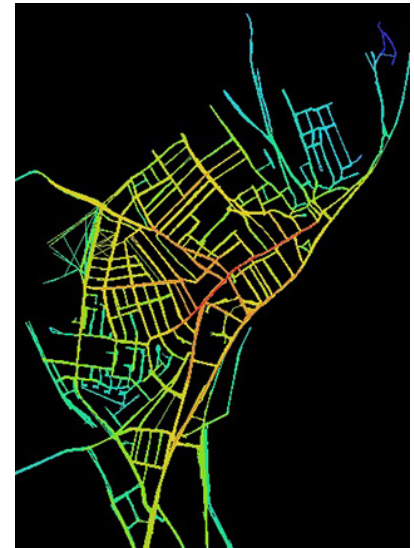

(b)

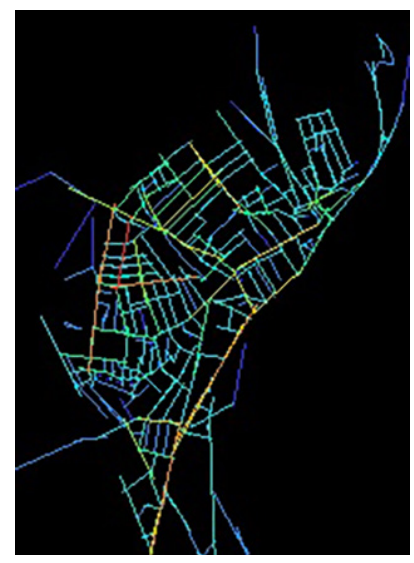

(d)
Fig. 7 Space syntax analyses of Paks, (a) Integration axial map with present urban structure, (b) Integration axial map with future urban structure, (c) Connectivity axial map with presence city structure,

(d) Connectivity axial map with new city structure,

Rating: strong: red, weak: blue, testing created by the author

\section{References}

Ambró, P., Jakab, I., Keresztély, D., Nemere, L., Némethy, Z., Párkányi, Gy., Tóth, J., Valtinyi D. (1996) "Panelkalauz - karbantartás, korszerüsítés, felújítás", (Panel Guide - maintenance, modernization, renewal) 1st ed., Építésügyi Tájékoztatási Központ Kft., Budapest, Hungary. (in Hungarian)

Balla, R. (2016) "Housing Estates in Towns: Bökényalj in Csongrád", Régi-új Magyar Építőművészet, Utóirat, 16(3), pp. 72-74.

Balla, R., Benkő, M., Durosaiye, I. O. (2017) "Mass Housing Estate Location in Relation to Its Livability: Budapest Case study", In: Cities, Communities and Homes: Is the Urban Future Livable? Conference, Derby, United Kingdom, pp. 192-203. [pdf] Available at: http://www.urbanisztika.bme.hu/wp-content/uploads/2018/04/ AMPS-Proceedings-10-Cities-Communities-Homes-Is-theUrban-Futire-Livable-1_BALLABENK\%C5\%90DURA.pdf [Accessed: 1st May 2018]

Benkő, M., Balla, R. (2016) "Fundamentum - A paneles lakóépületek földszintje", (Fundamentum - The ground floor of a prefabricated block of flats) Építés - Építészettudomány, 44(3-4), pp. 317-332. (in Hungarian)

https://doi.org/10.1556/096.2016.44.3-4.5

\section{Conclusions}

Sustainable strategic measurements offer not only suitable but also adequate tools for the evaluation of existing housing estates. To succeed, it is necessary to rescale the territorial arrangement of the units, and through strategies based on the principles of sustainable territorial development, make changes possible. By including the issues in the longterm development plan, we can deliberately improve housing estates, although, in practice, we should apply those analyses that are sensitive not only to the housing function of the estates but also to the problematics of their integration into the urban network. In this respect, it is important to make a distinction regarding the size of the settlements, as the position of the housing estates is different in bigger cities compared to small and mid-sized towns.

Benkö, M., Balla, R., Hory, G. (2018) "Participatory Place-making in the Renewal of Post-Communist Large Prefabricated Housing Estate: Újpalota Case Study, Budapest", Journal of Place Management and Development, 11(2), pp. 223-241. https://doi.org/10.1108/JPMD-06-2017-0050

Benkő, M. (2015) "Budapest's Large Prefab Housing Estates: Urban Values of Yesterday, Today and Tomorrow", Hungarian Studies, 29(1-2), pp. 21-36.

https://doi.org/10.1556/044.2015.29.1-2.2

Csizmady, A. (2003) "A lakótelep", (The housing estate) 1st ed., Gondolat Kiadó, Budapest, Hungary. (in Hungarian)

Csizmady, A. (2008) "A lakóteleptől a lakóparkig", (From housing estates towards gated residential community), 1st ed., Új Mandátum Kiadó, Budapest, Hungary. (in Hungarian)

Egedy, T. (2000) "The Situation of High-Rise Housing Estates in Hungary", In: Kovács, Z. (ed.) Hungary towards the $21^{\text {st }}$ Century - the Human Geography of Transition, Studies in geography in Hungary, 31, Geographical Research Institute, Research Centre for Earth Sciences, Hungarian Academy of Sciences, Budapest, Hungary, pp. 169-185. 
Fleischer, T. (2009) "A közlekedés szerepe a policentrikus városhálózat fejlesztésében", (The Role of the Transportation in the Development of a Polycentric Urban Network) Tér és Társadalom, 23(1), pp. 19-42. [pdf] Available at: http://www.vki.hu/ tfleisch/PDF/pdf09/ fleischer_policentrikus_TeT-2009-1.pdf [Accessed: 2nd October 2017] (in Hungarian)

Frampton, K. (2007) "Modern Architecture: A Critical History", 4th ed., Thames and Hudson, London, United Kingdom.

Fürstand, A. (2007) "Térszintaktika a településkutatásban", (Space syntax in the research of settlements) PhD Thesis, Corvinus University of Budapest, Budapest, Hungary. [pdf] Available at: http://phd. lib.uni-corvinus.hu/283/1/furstand_attila.pdf [Accessed: 15th November 2017] (in Hungarian)

Gábor, P., Helembai, M., Hoskó, L. (2015) "A Vizafogó lakótelep zöldterületi felújítása, ahogy a lakók látják", (Rehabilitation of the green area in Vizafogó housing estate according to residents), [online] Available at: http://epiteszforum.hu/a-vizafogo-lakotelep-zoldteruleti-felujitasa-ahogy-a-lakok-latjak [Accessed: 28th September 2015]

Gelesz, A. (2012) "Paneles lakótelepek felújitási lehetőségei környezetés energiatudatos minősítő rendszerek szempontrendszerének figyelembevételével", (Renewal opportunities of prefabricated mass housing estates with concerning environmentally and energy-conscious qualification systems) Diploma Thesis, University of Debrecen, Debrecen, Hungary. (in Hungarian)

Gere, L. (2012) "Village Block renovation pilot project, district 3, Óbuda, Budapest", [online] Available at: https://www.eukn.eu/news/ detail/village-block-renovation-pilot-project-district-3-obuda-budapest/ [Accessed: 24th September 2012]

Hallek, M. (1974) "Development of Paks", Településrendezés, 4(3),

Hillier, B., Hanson, J. (1984) "The Social Logic of Space", 1st ed., Cambridge University Press, Cambridge, United Kingdom.

HitesyBartuczHollai Euroconsulting Kft. (2014) "Liveable - Sustainable Havanna, LOCAL ACTION PLAN 2014-2020", URBACT RE-Block project, [pdf] Available at: http://urbact.eu/sites/default/ files/re-block_lap_budapest.pdf [Accessed: 9th September 2014]

ingatlannet.hu (2018) "Ingatlan statisztikák országosan", (Property Market Statistics of Hungary) [online] Available at: https://www. ingatlannet.hu/statisztika/Magyarorsz\%C3\%Alg [Accessed: 2nd May 2018] (in Hungarian)

Klasander, A.-J. (2005) "Challenges of the modernist urban landscape: On urban design and (sub)urban space", Nordisk Architekturforskning (Nordic Journal of Architectural Research), 18(1), pp. 37-46. [online] Available at: http://arkitekturforskning. net/na/article/download/194/157 [Accessed: 22 October 2013]
Körmendi, K. (1973) "Az új városok helye a magyar településhálózatban", (New towns in the Hungarian settlement network), Városépítés, 10(4), pp. 6-7. (in Hungarian)

Körner, Zs., Nagy, M. (2006) "Az európai és a magyar telepszerü lakásépítés története 1945-töl napjainkig", (The history of European and Hungarian development of housing estates from 1945 to the present) 1st ed., Terc Kiadó, Budapest, Hungary. (in Hungarian)

Le Corbusier (1946) "The Athens Charter", The Library of the Graduate School of Design, Harvard University, Paris, France.

Le Corbusier (1973) "The Athens Charter", New ed., [pdf] Grossman Publishers, New York, United States. Available at: https:// jasonsedar.files.wordpress.com/2011/03/the_athens_charter.pdf [Accessed: 2nd November 2017]

Lukovich, T. (2001) "A posztmodern kor városépítészetének kihívásai", (The Challenges of Urban Design of the Postmodern Age) 2nd ed., Pallas Stúdió, Budapest, Hungary. (in Hungarian)

Lukovich, T., Mogyorósi, K. (2013)"Fenntartható fejlesztés - Várostervezési útmutató", (Sustainable Development - Urban Planning Guide) 1st ed., Terc Kiadó, Budapest, Hungary. (in Hungarian)

Marnitz, I. (2017) "Panelbontás helyett reneszánsz", (Instead of demolition, prefab housing renaissance) Népszava Journal, [online] Available at: http://nepszava.hu/cikk/1141552-panelbontas-helyett-reneszansz [Accessed: 27th September 2017] (in Hungarian)

Orova, M., Reith, A. (2015) "Comparison and Evaluation of Neighbourhood Sustainability Assessment Systems", In: PLEA 2013 - 29 $9^{\text {th }}$ Conference, Sustainable Architecture for a Renewable Future, Munich, Germany, [pdf] Available at: http://mediatum.ub. tum.de/doc/1169262/1169262.pdf [Accessed: 12th September 2013]

Perry, C. A. (1998) "The Neighbourhood Unit", (1929) Reprinted ed., Routledge/Thoemmes, London, United Kingdom.

Rudlin, D., Falk, N., (2009) "Sustainable Urban Neighbourhood: Building the $21^{\text {st }}$ Century Home", 2nd ed., Routledge, Oxford, United Kingdom.

U.S. Green Building Council (USGBC) (2018) "LEED v4 for Neighbourhood Development", [pdf] Available at: https://www. usgbc.org/sites/default/files/LEED\%20v4\%20ND_01.5.18_current.pdf [Accessed: 5th January 2018] 